\title{
Review on Fenugreek (Trigonella foenum-graecum L.) and its Important Secondary Metabolite Diosgenin
}

\author{
Spandan CHAUDHARY ${ }^{1 *}$, Pooja Shah CHAUDHARY ${ }^{1}$, \\ Surendra K. CHIKARA ${ }^{1}$, Mahesh C. SHARMA ${ }^{2}$, Marcello IRITI ${ }^{3 *}$ \\ ${ }^{1}$ Xcelris Labs Ltd, Old Premchand Nagar Road, Opp. Satyagrah Chhavani, Bodakdev, Ahmedabad, Gujarat, \\ India; spandan.chaudhary@gmail.com (*correspondingauthor);pooja.chaudhary@xcelrislabs.com; surendrakchikara@gmail.com \\ ${ }^{2}$ Kadi Sarva Vishwavidyalaya, II Floor, KBIPER Building, Kadi Campus, Sector-23, Gandhinagar-382023, \\ India; mc_sharma2@rediffmail.com \\ ${ }^{3}$ Milan State University, Department of Agricultural and Environmental Sciences, 2 Via G. Celoria, 20133 Milan, \\ Italy;marcello.iriti@unimi.it (*orrespondingauthor)
}

\begin{abstract}
Fenugreek (Trigonella foenum-graecum L.) is a medicinal plant used worldwide since ancient times. Its use as smelling agent and spice was documented since $15^{\text {th }}$ century. The genus Trigonella includes around 260 species diffused worldwide and belonging to Fabaceae family. In the last decades, a number of studies highlighted the biological activities and therapeutic properties of this species mainly attributed to bioactive secondary metabolites such as alkaloids, flavonoids, steroids and saponins. In particular, diosgenin, a steroidal saponin, has been investigated for its medicinal uses and fenugreek has been reported as source of raw material for the production of steroidal hormones. This review article focuses on the cultivation, genetics, ecophysiology and traditional uses of fenugreek, as well as on its medicinal properties, phytochemical and nutrient contents. Extraction procedures and pharmacological activities of diosgenin are also reviewed, as well as methods for its chemical analyses. This review focuses on the medicinal importance of Fenugreek and its important secondary metabolite diosgenin. The review article complies the results of pre-clinical studies conducted to establish the various medicinal applications of diosgenin. This will help researcher to discover fundamental role of diosgenin as a potential product for drug manufacturers and use of fenugreek as a source of diosgenin.
\end{abstract}

Keywords: ethnobotany, ethnopharmacology, Fabaceae, saponins, sex hormones, steroids

\section{Introduction}

Trigonella foenum-graecum L. (fenugreek) is widely used for its medicinal properties all over the world and it is a very important spice in Indian culture. Around 260 species of Trigonella are diffused worldwide (Acharya, 2006). The genus name Trigonella means 'tri-angled', maybe because of triangular shape of its flowers, whereas the species name foenum-graecum means 'Greek hay' (Petropoulos, 2002). It is an annual crop and dicotyledonous plant belonging to the subfamily Papilionaceae, family Fabaceae. The plant is erect or branched and, generally, grows to a height of about 30-60 $\mathrm{cm}$, depending on the variety. It has trifoliate, pinnate leaves; roots bearing nodules; white to yellow flowers, flowering 30-40 days after sowing; $3-15 \mathrm{~cm}$ long, thin pointed, hoop-like pods; golden yellow seeds (Petropoulos, 2006; Basch et al., 2003; Acharya, 2008; Moradi and Moradi, 2013).
It is believed that fenugreek was native from Europe, though De Candolle mentioned that it could be a plant from Indian origin. If fenugreek was from European origin, then, it should be common in Europe, but this is not the case. Fazli and Hardman reported that fenugreek was native from Punjab and Kashmir, Mesopotamia desert, Persia and some European countries as Greece, Italy and Spain (Linnaeus, 1753; De Candolle, 1886; Fazli and Hardman, 1968). The fenugreek leaves were used to produce the Egyptian incense Kuphi, a holy smoke used in fumigation and embalming rites (Rosengarten, 1969). Well documented fenugreek uses date back to $15^{\text {th }}$ century. Melius compiled the details of this plant species in the wellknown Kolozsvar Herbarium, in 1578 (Petropoulos, 2003). Hidvegi mentioned some uses of fenugreek, in $16^{\text {th }}$ century (Hidvegi, 1984). Howard reported that the fenugreek seed powder was used, in $17^{\text {th }}$ century, to expel placenta after child birth (Howard, 1987). Despite its uses since centuries, 
fenugreek was not studied in detail in the past, even if, since the last decades, its biological activities are seeking attention of the scientific community.

This review article focuses on the genetics of fenugreek, as well as on its medicinal properties, phytochemical and nutrient contents. Extraction procedures and pharmacological activities of diosgenin are also reviewed, as well as methods for its chemical analyses.

\section{Fenugreek Plant}

\section{Fenugreek cultivation, varieties and uses in the world}

Fenugreek has good adaptability to diverse atmospheric conditions, temperatures and soils which makes it cultivable in different habitats and more than 20 countries of Asia, Europe, Africa, America and in some areas of Australia (Fig. 1 ), where it is used as food ingredient, flavoring agent, herb and spice (Rouk and Mangesha, 1963; Fazli and Hardman, 1968; Rosengarten, 1969). In India, fenugreek is cultivated mainly in Rajasthan (around $80 \%$ of the national production), Gujarat, Uttaranchal, Uttar Pradesh, Madhya Pradesh, Maharashtra, Haryana and Punjab.

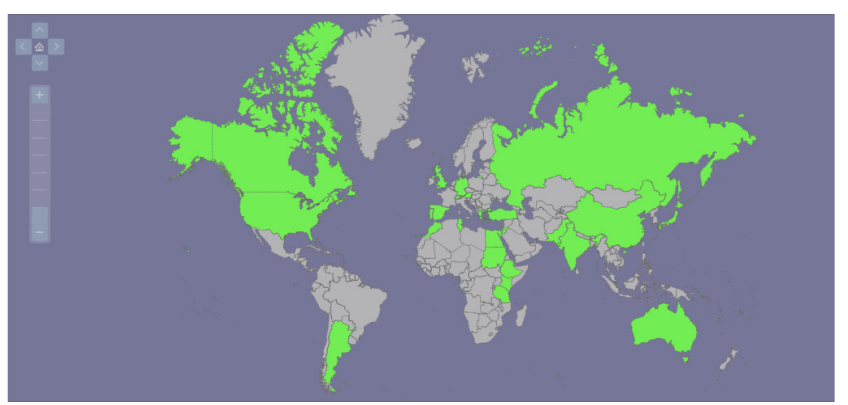

Fig. 1. Cultivation of Trigonella foenum-graecum L. in the world; in green, countries were fenugreek is cultivated
Diverse fenugreek genotypes are present in the world, differing in growth habits, morphology, seed quality and crop yield. Since fenugreek is a self-pollinating plant, breeders successfully developed varieties by using breeding techniques. Some of the most important fenugreek varieties diffused throughout the world are summarized in Table 1.

Nowadays, fenugreek is used in various countries: as spice in Iran, for preparing flavor cheese in Switzerland, seed powder along with flour for making flat bread in Egypt, seedlings as vegetable in India and Pakistan (Moradi and Moradi, 2013). In Africa, people use fenugreek seeds as coffee-substitute, to control insect infestations in grain storages, in cosmetic industries and so on.

\section{Fenugreek genetics}

The few data available on fenugreek kariotype and genome have identified the somatic chromosome numbers of Trigonella taxa as $2 n=14,16,30$ and 46 along with B chromosomes (Martin et al., 2011; Vaidya et al., 2013). The $\mathrm{C}$-value of fenugreek was found to be 0.7 , which is 1.5 fold higher than the values of model legumes Lotus corniculatus L. var. japonicus Regel [syn. Lotus japonicus (Regel) K. Larsen] and barrel (Medicago truncatula Gaertn.); genome size of both these species is around $470 \mathrm{Mbp}$, whereas the genome size of fenugreek is around $685 \mathrm{Mbp}$ (Young et al., 2003; Vaidya et al., 2013). Despite fenugreek is an important medicinal plant, its whole genome sequencing has not been carried out yet, and only transcriptome sequencing data were published earlier by our research group. The transcriptome contains 42 million high quality reads, with 18,333 transcripts functionally annoted and 6,775 transcripts related to metabolic pathways including diosgenin biosynthesis (Vaidya et al., 2013). In particular, targeting transcriptome sequencing of fenugreek has been

Table 1. List of fenugreek varieties available worldwide

\begin{tabular}{|c|c|c|}
\hline Fenugreek Variety & Country & References \\
\hline CO-1, Rajendra Kanti, RMt-1, LamSel 1, Pusa Early Bunching & India & Edison (1995) \\
\hline $\begin{array}{l}\text { UM-9, UM-17, UM-18, UM-23, UM-25, UM-26, UM-27, UM-32, UM-33, UM-36, UM-50, UM-52, UM-58, } \\
\text { UM-67, UM-70, UM-75, UM-77, UM-79, UM-83, UM-84, M-105, UM-112, UM-113, UM-114, UM-115, CVT } \\
\text { UM-5, CVT UM-17, CVT UM-32, CVT UM-34, CVT UM-35, CVT UM TC 2336, CVT TG 1084, CVT GF } \\
\text { 1, CVT CC, CVT NLM, NLM, CO 1, Local check, CT Lam Sel } 1\end{array}$ & India & Kamal et al. (1987) \\
\hline $\begin{array}{l}\text { RG-07, TG-3, TG-13, TG-18, TG-24, TG-34, UM-5, UM-6, UM-17, UM-20, UM-34, UM-35, UM-38, NI-01, } \\
\text { MP-14, IC-99, LamSel 1, Local Bobes, Pusa Earlier, Bangalore-Local }\end{array}$ & India & Prasad and Hiremath (1985) \\
\hline $\mathrm{T}-8$ & India & Paroda and Karwasra (1975) \\
\hline HM-46 & India & Singh et al. (1994) \\
\hline IC-74 & India & Singh and Singh (1974) \\
\hline 'Gharbin-6’ & Egypt & Bunting (1972) \\
\hline 'Ali Lunghe', 'Ali Corte' & Italy & Del' Gaudio (1953) \\
\hline Ionia & Greece & Vaitsis (1985); Anonymous (1996) \\
\hline Gouta & France & Haefele et al. (1997) \\
\hline Fluorescent, Ethiopian & England & Petropoulos (1973) \\
\hline Barbara, Margaret, Paul & England & Hardman (1980); Evans (1991) \\
\hline Fluorescent, Ethiopian, Kenyan, Moroccan & England & Petropoulos (1973) \\
\hline
\end{tabular}


24

studied by Vaidya $e t a l$. in order to identify the genes of diosgenin pathway (Vaidya et al., 2013). Studies on fenugreek genome should be improved, since they could provide information about the bioactive phytochemicals of this important medicinal plant.

\section{Ecophysiology of fenugreek plants}

As previously introduced, fenugreek is widely distributed in most parts of the world because of its adaptation to different climatic conditions and environments (Fig. 1). This plant is tolerant to drought and able to grow well in areas with moderate to low rainfall; its temperature requirement is as low as $10-15^{\circ} \mathrm{C}$, though it can neither grow well in extreme high nor in extreme low temperatures (Talelis, 1967; Duke, 1986). For instance, in Greece, fenugreek is cultivated both in summer and winter, because of its adaptive nature (Talelis, 1967). It has been reported that the maximum fenugreek yield occurs in areas where dry season with low temperatures follows rainy season, which are the typical subtropical and Mediterranean conditions. Ethiopian fenugreek is cultivated in areas having climatic conditions similar to the Mediterranean region ones (Rouk and Mangesha, 1963). In India and Egypt, fenugreek is grown in winter (Pareek and Gupta, 1981), though in Germany it is cultivated at the beginning of spring. For Indian weather, early sowing around the middle of October gave higher yields than late sowing around the middle of November (Rathore and Manohar, 1989). Crop improvement can play significant role in increasing yield for any plant. Many studies demonstrated work for fenugreek crop improvement (Petropoulos, 2002; Acharya et al., 2008). Different crop improvement techniques are popular from which majorly used methods are: consequent selection from all available accessions, artificial crossing and mutational breeding. In case of fenugreek, artificial crossing is difficult because it is self-pollinated plant. Mutational breeding and consequent selection among world accessions are better ways to improve the crop (Petropoulos, 2002), and much of the breeding with fenugreek has utilized these two approaches.

\section{Fenugreek phytochemicals and nutrients}

The three main classes of fenugreek secondary metabolites include saponins, flavonoids and alkaloids. This plant seeds were reported to contain 35\% alkaloids, $10 \%$ flavonoids (100 mg per $\mathrm{g}$ of fenugreek seeds), $4.8 \%$ saponins and $0.2-0.9 \%$ diosgenin (Jani, 2009; Meghwal, 2012; Vaidya, 2013). Alkaloids, along with some other volatile compounds, are mainly responsible for the bitter taste and typical aroma of fenugreek (Kumar, 2012, Faeste, 2009). Additionally, it is a significant source of vitamin $B_{1}$, iron, silicon, sodium, protein, amino acids, fatty acids and dietary fiber (Sharma et al., 1990). In particular, the plant is rich in soluble fiber, mucilage and galactomannan which decrease the uptake of bile salts and starch absorption (Madar, 1990). Fenugreek seeds contain the amino acid 4hydroxyisoleucine which increases insulin secretion (Haefelé et al., 1997). The plant also represents a significant source of antioxidants (Naidu, 2011). In obese subjects, short-term beneficial effects of fenugreek fiber were reported on satiety, blood glucose, insulin response and energy intake (Mathern et al., 2009). In addition, fenugreek fiber can bind to and remove carcinogens in the intestine (Meghwal, 2012).

\section{Fenugreek traditional uses}

As previously introduced, fenugreek use as herbal remedy in traditional healing systems dates back to $15^{\text {th }}$ century. Dried seeds and leaves, in different forms, were used for curing many symptoms and ailments. For instance, a paste prepared with ground fenugreek seeds was used to treat eczema, rash or inflammatory conditions. Ethnoveterinary uses of fenugreek were also documented. Traditional uses of fenugreek are summarized in Table 2.

\section{Therapeutic properties}

A number of pharmacological activities have been investigated in order to clarify the therapeutic properties of fenugreek and its main metabolites (Mehrafarin et al., 2010). Some studies have been carried out on extracts from different plant parts (seeds, leaves) or pure phytochemicals (saponins, steroids, alkaloids) to validate traditional uses of fenugreek as herbal remedy. These studies, reported in Table 3, investigate, in some cases, the pharmacological mechanisms by different experimental models.

\section{Need of improvement in fenugreek cultivation}

In India, fenugreek was grown in 94,760 and 93,605 hectares, in the years 2010-2011 and 2011-2012, respectively, with a production of 12,785 and 11,529 million tons, respectively. The production of fenugreek was 1.34 and 1.23 million tons per hectare, in the years 20102011 and 2011-2012, respectively (Vidyashankar, 2014). In India, eight research and development projects were planned for spices including fenugreek along with research institutions and state universities under the All India Coordinated Research Project ${ }^{13}$. However, researchers found difficulties in growing fenugreek due to the lack of information regarding this plant (Petropoulos, 2002). Therefore, varieties and techniques to improve fenugreek quality and yield from poor lands are urgently needed in such scenario.

\section{Diosgenin}

As previously reported, fenugreek is a rich source of saponins such as yamogenin, tigogenin and diosgenin. Diosgenin is the most important out of all four mentioned secondary metabolites. It has a molecular weight of 414.621 $\mathrm{g}$ mol-1 and is made up of 27 carbon, 42 hydrogen and three oxygen atoms. Its scientific name is (3ß,25R)-spirost-5-en-3ol, $\mathrm{C} 27 \mathrm{H} 42 \mathrm{O} 3$ and its chemical structure is illustrated in Fig. 2. It has estrogenic activity and represents the most important bioactive phytochemical in fenugreek, used as raw precursor for the industrial, large scale synthesis of steroidal drugs and hormones such as testosterone, norethisterone, glucocorticoids and progesterone. Diosgenin also exhibited anticancer and antiaging activities, as well as cardioprotective and contraceptive properties (Aradhna et al., 1992; Liu et al., 1993; Qin et al., 1997; Dias et al., 2007; Lee et al., 2007; Tada et al., 2009; Yan et al., 2009; Gong et al., 2010; Agarwal et al., 2015). Russell Marker and colleagues developed the semisynthesis of 
Table 2. Traditional uses of fenugreek

\begin{tabular}{|c|c|c|}
\hline Plant parts and preparation & Symptoms or illnesses & References \\
\hline Seeds & Chapped lips, stomach irritation, mouth ulcers & Duke (1986) \\
\hline Soaked seeds & Constipation & Fazli and Hardman (1968); Rosengarten (1969) \\
\hline $\begin{array}{c}\text { Decoction } \\
\text { (various parts) }\end{array}$ & $\begin{array}{l}\text { Tuberculosis, sore throat, infection of stomach and intestine, remedy for gonorrhea and } \\
\qquad \text { vermin }\end{array}$ & $\begin{array}{l}\text { Schauenberg and Paris (1990); } \\
\text { Fazli and Hardman (1968) }\end{array}$ \\
\hline Poultice of seeds & $\begin{array}{l}\text { Gouty pains, neuralgia, sciatica, swollen glands, wounds, furuncles, fistulas, tumours, sores, } \\
\text { skin irritation, abscesses and carbuncles }\end{array}$ & $\begin{array}{l}\text { Sharma et al. (1996); } \\
\text { Pandian et al. (2002) }\end{array}$ \\
\hline Crushed seeds with powdered charcoal & Bruises, swellings, boils, ulcers, swelling of testicles & $\begin{array}{l}\text { Pandian et al. (2002); Bunney (1984); } \\
\text { Reger (1993) }\end{array}$ \\
\hline Seeds & Constipation and diarrhea & Evans (1991); Sharma et al. (1996) \\
\hline Poultice of seeds (in Malaya) & Burns, cough, dropsy, hepatomegaly, splenomegaly & Duke (1986); Bhatti (1996); Sharma et al. (1996) \\
\hline Seeds (in China) & $\begin{array}{c}\text { Abdominal and hypogastric pain, chilblains, cholecystitis, fever, hernia, impotence, nephrosis } \\
\text { and rheumatism }\end{array}$ & Duke (1986) \\
\hline Fenugreek tea & Soothing to the gastrointestinal tract & Pandian et al. (2002) \\
\hline Alcoholic fenugreek extracts & To expel poisons and unwanted materials from the human body & Howard (1987) \\
\hline Seeds & To prepare the base of medicinal preparation called 'Luddoo' & Rouk and Mangesha (1963) \\
\hline Seed powder & Inflammations and suppurations & Fluck (1988) \\
\hline Seeds (aqueous extract) & Antibacterial activity & Bhatti et al. (1996) \\
\hline Decoction of the seeds & Remedy for diabetes & $\begin{array}{l}\text { Evans (1991); Khosla et al. (1995); } \\
\text { Sharma et al. (1996) }\end{array}$ \\
\hline Decoction of the seeds & Substitute of insulin & Oliver-Bever (1986) \\
\hline Seeds & Anti-diabetic activity & $\begin{array}{l}\text { Daoud (1932); Valette et al. (1984); } \\
\text { Oliver-Bever (1986); Evans (1991); }\end{array}$ \\
\hline Seeds & To reduce serum cholesterol in animals & Sharma et al. (1991) \\
\hline Seeds & To increase milk production in animals & Bunney (1984) \\
\hline Seeds & Anticancer activity, fibromas & Singhal et al. (1982); Evans (1991) \\
\hline Seeds & To induce labour during child birth & Yoshikawa et al. (1997) \\
\hline Various parts & For treating weakness and oedema & Basch et al. (2003) \\
\hline
\end{tabular}

Table 3. Pharmacological activities of fenugreek

\begin{tabular}{|c|c|c|}
\hline Plant parts/ phytochemicals & Pharmacological activities & References \\
\hline Seed powder & Decrease of glycaemia, improvement of symptoms in type- 2 diabetes patients & Mitra and Bhattacharya (2006) \\
\hline Seeds & Decrease of glycaemia in type 2 diabetes patients & $\begin{array}{l}\text { Madar et al. (1988); Jain et al. } \\
\text { (1995); Sharma et al. (1996) }\end{array}$ \\
\hline Seeds & Diabetes control in type 1 diabetes patients & Sharma et al. (1990) \\
\hline 4-Hydroxyisoleucine extracted from seeds & Increase of insulin secretion & Sauvaire et al. (1998) \\
\hline Various parts & Increased number of insulin receptors & Raghuram et al. (1994) \\
\hline Various parts & Increase of insulin secretion in animals & Ethan et al. (2003) \\
\hline Alkaloids, flavonoids, saponins & Decrease of lipaemia, glycaemia and cholagogic for treating diabetes mellitus & Izzo et al. (2005) \\
\hline Extract rich in saponins & Decrease of hypercholesterolemia in rats & Petit et al. (1995) \\
\hline Seeds & Management of long-term diabetes complications & Ribes et al. (1986) \\
\hline Seeds & Decrease of glycemia in diabetic patients & $\begin{array}{c}\text { Sowmya and Rajyalakhsmi } \\
\text { (1999) }\end{array}$ \\
\hline Various parts & Treatment of hyperglycemia in type- 1 diabetic rats & Basch et al. (2003) \\
\hline Aqueous extract (various parts) & Ulcer protective & Srinivasan (2006) \\
\hline Diet with $30 \%$ fenugreek seeds & $\begin{array}{l}\text { In female rabbits: antifertility and reduction of developing foetuses } \\
\text { In male rabbits: decrease of testis weight, plasma concentration of androgens } \\
\text { and sperm production }\end{array}$ & Bin-Hafeez et al. (2003) \\
\hline Leaves and seeds & Reduction of perspiration, fever, allergies, bronchitis and congestion & Faeste et al. (2009) \\
\hline Seeds & Treatment of sinus and lung congestion & Singhal et al. (1982) \\
\hline
\end{tabular}


26

\begin{tabular}{|c|c|c|}
\hline Leaves and seeds & Antimicrobial & $\begin{array}{c}\text { Sowmya and Rajyalakhsmi } \\
\text { (1999) }\end{array}$ \\
\hline Leaves and seeds & Treatment of hypertension and hypercholesterolemia & $\begin{array}{l}\text { Sowmya and Rajyalakhsmi } \\
\text { (1999); Roberts (2012) }\end{array}$ \\
\hline Leaves and seeds & Prevention of gas formation in digestive tract & Mathern (2009) \\
\hline Steroids, flavonoids, alkaloids & Raw material for hormones and pharmaceuticals & Blank (1996) \\
\hline Leaves and seeds & Antibacterial, anticancer, antiulcer, antinociceptive & $\begin{array}{l}\text { Sowmya (1999); Mathern } \\
\text { (2009) }\end{array}$ \\
\hline
\end{tabular}

Table 4. Pharmacological activities of diosgenin

\begin{tabular}{|c|c|}
\hline Pharmacological activities & References \\
\hline Antifungal activity on Candida albicans, C. glabrata and C. tropicalis & Sautor (2004) \\
\hline Inhibition of replication of hepatitis $\mathrm{C}$ virus $(\mathrm{HCV})$ & Wang (2011) \\
\hline Decrease of glycaemia and intestinal disaccharidases in vivo & McAnuff (2006) \\
\hline $\begin{array}{l}\text { Decrease of the activity of the ATP-citrate lyase, pyruvate kinase and glucose-6-phosphate dehydrogenase in the liver of } \\
\text { diabetic rats }\end{array}$ & McAnuff (2005) \\
\hline Inhibition of glucose-uptake and glucagon-induced hepatic glycogen phosphorylase A activity in vitro & Al-habori (2001) \\
\hline Anticoagulant activity, inhibition of platelet aggregation and thrombosis in vivo & Gong (2011) \\
\hline Decrease of plasma total cholesterol and LDL-cholesterol, increase of HDL-cholesterol and total cholesterol ratio in rats & Xu et al. (2009) \\
\hline Enhancement of $\mathrm{BK}(\mathrm{Ca})$-channel activity in human cortical neurons & Wu $(2006)$ \\
\hline Decrease of blood pressure, oxidative stress and cardiac remodeling in the heart of adenine-induced chronic renal failure rats & Manivannan (2015) \\
\hline Increase of antioxidant level, decrease of ACE activity, lipid peroxidation level and cardiac fibrosis in chronic renal failure rats & Manivannan (2015) \\
\hline Inhibition of platelet aggregation and acetylcholinesterase activity & Sautour (2004) \\
\hline Decrease of serum total cholesterol levels in rats & Ghayur (2011) \\
\hline Inhibition of accumulation of triglycerides and expression of lipogenic genes in mice & Ma HY et al. (2002) \\
\hline In vivo increased levels of superoxide dismutase in the plasma and liver, glutathione peroxidase and catalases in erythrocytes & Uemura (2011) \\
\hline Upregulation of antioxidant enzymes in rats & Son et al. (2007) \\
\hline Suppression of inflammation within the atherosclerotic lesion in vivo & Son et al. (2007) \\
\hline Anti-inflammatory activity in RAW 264 macrophages induced by the conditioned medium derived from 3T3-L1 adipocytes & Choi et al. (2010) \\
\hline Food allergy, suppression of intestinal inflammation & Hirai et al. (2010) \\
\hline G0/G1 arrest and inhibition of proliferation induced by IGF-1 in human thyroid cells & Huang et al. (2009) \\
\hline Inhibition of migration and invasion of human prostate cancer PC-3 cells by reducing matrix metalloproteinase expression & Cai et al. (2014) \\
\hline $\begin{array}{c}\text { Regulation of Jun N-terminal kinase, phosphatidylinositide-3 kinase/Akt signaling pathways and NF- } \kappa \mathrm{B} \text { activity in human } \\
\text { prostate cancer PC-3 cells }\end{array}$ & Chen et al. (2011) \\
\hline Sensitization of HT-29 cells to TRAIL-induced apoptosis & Chen et al. (2011) \\
\hline Inhibition of tumor growth in MCF-7 and MDA-231 xenografts in nude mice & Lepage et al. (2011) \\
\hline Inhibition of melanogenesis by activating the PI3K pathway & Srinivasan et al. (2009) \\
\hline Apoptosis induction and growth inhibition of HCT-116 human colon carcinoma cells & Lee et al. (2007) \\
\hline Apoptosis induction and downregulation of COX-2 expression and activity in human rheumatoid synovial cells & Raju and Bird (2007) \\
\hline Inhibition of viability and proliferation of breast cancer cells & Liagre et al. (2007) \\
\hline Osteoclastogenesis suppression by inhibiting NF-kappaB-regulated gene expression & Li et al. (2005) \\
\hline Growth inhibition and apoptosis induction in HT-29 human colon cancer cells & Shishodia and Aggarwal (2006) \\
\hline p53 activation and cell cycle arrest in the different cell lines & Raju et al. (2004) \\
\hline Anticancer activity on S-180, HepA, U14 transplant mice and L929, HeLa, MCF cells & Corbiere et al. (2004) \\
\hline Normalization of lipid levels by excretion through faeces in diabetic rats & Wang et al. (2002) \\
\hline
\end{tabular}

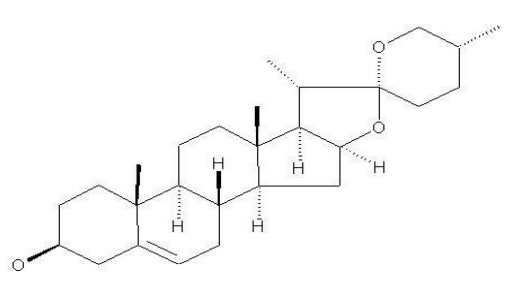

Fig. 2. Chemical structure of Diosgenin $(3 \beta, 25 R)$-spirost-5-en3-ol) $\left[\mathrm{C}_{27} \mathrm{H}_{42} \mathrm{O}_{3}, 414.621 \mathrm{~g} \mathrm{~mol}^{-1}\right]$ progesterone from diosgenin at Parke-Davis Pharmaceutical Company, in 1940. Progesterone is produced in various formulations by many pharmaceutical companies for hormone replacement therapy during menopause. Noteworthy, in US, the overall market for this therapy is above $\$ 3.7$ billion. Medicinal uses of diosgenin are summarized in Table 4.

Diosgenin extraction methods

Different methods have been reported for the extraction 
of crude saponins and pure diosgenin from fenugreek tissues. Separation and extraction of diosgenin can be carried out by thin-layer chromatography (TLC) or highperformance thin-layer chromatography (HPTLC), whereas, in other methods, it can be extracted directly in pure form. In the method described by Li et al. (2012), diosgenin was extracted from cultured cells of Dioscorea zingiberensis. Cells were ground to a fine powder which was immersed in $95 \%$ ethanol, subjected to sonication, for $2 \mathrm{~h}$, followed by hydrolysis at $121^{\circ} \mathrm{C}$, for $2 \mathrm{~h}$, with $1 \mathrm{~mol} / \mathrm{L}$ sulfuric acid. Then, the hydrolysate was extracted thrice with petroleum ether followed by washing with $1 \mathrm{~mol} / \mathrm{L}$ $\mathrm{NaOH}$ and distilled water until it became colorless. The petroleum ether fraction was concentrated to dryness and, finally, dissolved in acetonitrile followed by filtration using $0.22 \mu \mathrm{m}$ filter for HPLC analysis (Li et al., 2012). In the diosgenin extraction method by Trivedi et al. (2007) powder from fenugreek stem, leaf and seed tissues was refluxed with $2.5 \mathrm{M}$ ethanolic sulfuric acid at $80^{\circ} \mathrm{C}$, for $4 \mathrm{~h}$, cooled and filtered through Whatman filter No. 1. The filtrate was diluted with water and extracted with chloroform which was, then, evaporated on water bath and further eluted in chloroform, before separating on TLC plates (Trivedi et al., 2007). In this method, $n$-hexane can also be used instead of chloroform to extract diosgenin, which can be dried and dissolved in acetonitrile followed by filtration through $0.22 \mu \mathrm{m}$ filter. This method yields pure diosgenin without extraction through TLC or other methods.

\section{Diosgenin determination and measurement}

Some methods for determination of diosgenin extracted from various plant tissues have been developed, including spectrophotometry, TLC, HPTLC, high-performance liquid chromatography (HPLC) and gas chromatography (GC). In the spectrophotometric method described by Baccou et al. (1977) and Uematsu et al. (2000) and modified by Chapagain and Wiesman (2005), plant extracts were treated with anisaldehyde, sulfuric acid and ethyl acetate to be measured at $430 \mathrm{~nm}$ for diosgenin determination. Trivedi et al. (2007) used calibration curve method for quantifying the extracted diosgenin: they found the green color spot on the TLC plate corresponding to diosgenin at $\mathrm{Rf}=0.30 \pm 0.04$ and visualized the same in scanner III at 428nm (Trivedi et al., 2007). Li et al. (2012) developed a spectrophotometric method to quantify diosgenin. They dissolved the compound in acetonitrile and evaporated it till dryness at room temperature followed by dissolving diosgenin in perchloric acid and measuring at 410 $\mathrm{nm}$. They also developed a HPLC method for diosgenin analysis and reported a retention time $(\mathrm{RT})=18.064 \pm$ 0.096 for this compound.

\section{Conclusions}

Fenugreek is a medicinal plant used, since centuries, as herbal remedy in many traditional healing systems. This plant also represents a significant source of diosgenin, a saponin used as precursor for the synthesis of steroid hormones. Preclinical studies investigated the pharmacological activities of fenugreek and its main metabolite diosgenin, focusing on their anti-diabetes, cardioprotective, anticancer and antimicrobial properties. Noteworthy, fenugreek can be a more suitable alternative for diosgenin production than the conventional method using yams, due to ease of production, short life cycle and less cost. However, the main limitation is the natural occurrence of diosgenin present in fenugreek, which is around $0.2-0.9 \%$. Therefore, this plant can be targeted to increase the yield both in terms of biomass and secondary metabolite production by different strategies, including genetic engineering, classic breeding, cultivation techniques and agricultural practices such as the use of fertilizers (Basu et al., 2009; Ahmed et al., 2010). Intriguingly, the use of elicitors, such as methyl jasmonate, was shown to significantly increase the yield of diosgenin from fenugreek plants, upregulating genes involved in its biosynthetic pathway (Chaudhary et al., 2015).

In conclusion, despite the topics focused in this review article, various issues related to fenugreek biology, phytochemistry and pharmacology still remain to be investigated, as well as the therapeutic properties of diosgenin need to be substantiated by randomized clinical trials. In the future, all these aspects could further improve the economic, industrial and medical relevance of these natural resources.

\section{Acknowledgements}

Authors are grateful to management of Xcelris Labs Ltd. for providing required resources to complete this review article.

\section{References}

Acharya SN, Thomas JE, Basu SK (2006). Fenugreek: an "old world” crop for the "new world". Biodiversity 7(3-4):27-30.

Acharya SN, Thomas JE, Basu SK (2008). Fenugreek, an alternative crop for semiarid regions of North America. Crop Science 48(3):841-853.

Agarwal M Agarwal M, Jain SC (2015). In vitro regulation of bioactive compounds in Trigonella species by mutagenic treatments. Journal of Plant Sciences 3:40-44.

Ahmed MA, Ibrahim OM Elham AB (2010) Effect of bio and mineral phosphorus fertilizer on the growth, productivity and nutritional value of fenugreek (Trigonella foenum-graecum L.) in newly cultivated land. Research Journal of Agriculture and Biological Sciences 6(3):339-48.

Al-Habori M, Raman A, Lawrence MJ, Skett P (2001). In vitro effect of fenugreek extracts on intestinal sodium-dependent glucose uptake and hepatic glycogen phosphorylase A. International Journal of Experimental Diabetes Research 2(2):91-99.

Baccou JC, Lambert F, Sauvaire Y (1977). Spectrophotometric method for the determination of total steroidal sapogenin. Analyst 102(1215):458-465.

Basch E, Ulbricht C, Kuo G, Szapary P, Smith M (2003). Therapeutic applications of fenugreek. Alternative Medicine Review 8(1):20-27.

Basu SK, Acharya SN, Bandara MS, Friebel D, Thomas JE (2009). Effects of genotype and environment on seed and forage yield in fenugreek (Trigonella foenum-graecum L.) grown in western 
Canada. Australian Journal of Crop Science 3(6):305.

Bhatti MA, Khan MTJ, Ahmed B, Jamshaid M, Ahmad W (1996). Antibacterial activity of Trigonella foenum-graecum seeds. Fitoterapia 67:372-374.

Bin-Hafeez B, Rizwanul H, Suhel P, Suwarna P, Iqbal S, Raisuddin S (2003).Immunomodulatory effects of fenugreek (Trigonella foenum-graecum L.) extract in mice. International Immunopharmacology 3(2):257-265.

Blank I (1996). The flavor principle of fenugreek. Nestlé Research Center. In: 211th ACS Symposium. New Orleans pp 24-28.

Bunney S (1984). The illustrated book of herbs: their medicinal and culinary uses. Vol 1, No 2. London: Octopus Books pp 320.

Cai H, Wang Z, Zhang HQ, Wang FR, Yu CX, Zhang FX, Gao L, Zhang J, Zhao JJ (2014). Diosgenin relieves goiter via the inhibition of thyrocyte proliferation in a mouse model of Graves' disease. Acta Pharmacologica Sinica 35(1):65-73.

Chapagain B, Wiesman Z (2005). Variation in diosgenin level in seed kernels among different provenances of Balanites aegyptiaca Del (Zygophyllaceae) and its correlation with oil content. African Journal of Biotechnology 4(11):1209-1213.

Chaudhary S, Chikara SK, Sharma MC, Chaudhary A, Syed AB, Chaudhary PS, ... Iriti M (2015). Elicitation of diosgenin production in Trigonella foenum-graecum (fenugreek) seedlings by methyl jasmonate. International Journal of Molecular Sciences 16(12):29889-29899.

Chen PS, Shih YW, Huang HC, Cheng HW (2011). Diosgenin, a steroidal saponin, inhibits migration and invasion of human prostate cancer PC-3 cells by reducing matrix metalloproteinases expression. PLoS One 6(5):e20164.

Choi KW, Park HJ, Jung DH, Kim TW, Park YM, Kim BO, Sohn EH, Moon EY, Um SH, Rhee DK, Pyo S (2010). Inhibition of TNF- $\alpha$-induced adhesion molecule expression by diosgenin in mouse vascular smooth muscle cells via down regulation of the MAPK, Akt and NF-kB signaling pathways. Vascular Pharmacology 53(5):273-280.

Corbiere C, Liagre B, Terro F, Beneytout J (2004). Induction of antiproliferative effect by diosgenin through activation of $\mathrm{p} 53$, release of apoptosis-inducing factor (AIF) and modulation of caspase-3 activity in different human cancer cells. Cell Research 14(3):188-196

Daoud KM (1932). The reserve polysaccharide of the seeds of fenugreek: its digestibility and its fate during germination. Biochemical Journal 26(1):255.

De Candolle A (1886). Origin of cultivated plants (Hafner, New York, 1967). English translation of the second edition, pp 316-321.

Del' Gaudio S (1953). Ricerche sui consumi idrici e indagini sull'autofertilita del fieno greco [Investigations on water consumption and surveys on the autochthonous hay greco]. Annali della Sperimentazione Agraria 7:1273-1287.

Dias KLG, de Azevedo CN, Pereira KKG, Barbosa-Filho JM, Cavalcante KVM, Araújo IGA, ... Medeiros IA (2007).

Mechanisms involved in the vasodilator effect induced by diosgenin in rat superior mesenteric artery. European Journal of Pharmacology
574(2):172-178.

Duke AJ (1986). Handbook of legumes of world economic importance. Springer Science \& Business Media.

Edison S (1995). Spices research support to productivity. In: Ravi N (Ed). The Hindu Survey of Indian Agriculture. Kasturi \& Sons Ltd, National Press, Madras pp 101-105.

Ethan B, Grace K, Michael S (2003). Therapeutic applications of fenugreek. Alternative Medicine Review 8(1):20-27.

Evans WC (1991). Trease and Evan's pharmacognosy, 13th edition. Balliere Tindall, London.

Faeste CK, Namork E, Lindvik H (2009). Allergenicity and antigenicity of fenugreek (Trigonella foenum-graecum) proteins in foods. Journal of Allergy and Clinical Immunology 123(1):187-194.

Fazli FRY, Hardman R (1968). The spice fenugreek (Trigonella foenum-graecum $\mathrm{L}$.). Its commercial varieties of seed as a source of diosgenin. Tropical Science 10:66-78.

Fluck H (1988). Medicinal Plants. W Foulsham \& Co Ltd, London.

Ghayur MN, Kazim SF, Rasheed H, Khalid A, Jumani MI, Choudhary MI and Gilani AH (2011). Identification of antiplatelet and acetylcholinesterase inhibitory constituents in betel nut. Journal of Chinese integrative medicine 9(6):619-625.

Gong G, Qin Y, Huang W, Zhou S, Wu X, Yang X, Zhao Y and Li D (2010). Protective effects of diosgenin in the hyperlipidemic rat model and in human vascular endothelial cells against hydrogen peroxide-induced apoptosis. Chemico-Biological Interactions $184(3): 366-375$.

Gong G, Qin Y, Huang W (2011). Anti-thrombosis effect of diosgenin extract from Dioscorea zingiberensis $\mathrm{CH}$ Wright in vitro and in vivo. Phytomedicine 18(6):458-463.

Haefele C, Bonfils C, Sauvaire Y (1997). Characterization of a dioxygenase from Trigonella foenum-graecum involved in 4 hydroxyisoleucine biosynthesis. Phytochemistry 44(4):563-6.

Hardman R (1980) Fenugreek -a multi-purpose annual legume for Europe and other countries. Cereal Unit Publication, Royal Agricultural Show, Stoneleigh, UK.

Hidvegi M, El-Kady A, Lásztity R, Bekes F, Simon SL (1984). Contribution to the nutritional characterization of fenugreek (Trigonella foenum-graecum L.). Acta Alimentaria 13(4):315-24.

Hirai S, Uemura T, Mizoguchi N, Lee JY, Taketani K, Nakano Y, Hoshino S, Tsuge N, Narukami T, Yu R, Takahashi N (2010). Diosgenin attenuates inflammatory changes in the interaction between adipocytes and macrophages. Molecular Nutrition \& Food Research 54(6):797-804.

Howard M (1987). Traditional folk remedies: A comprehensive herbal. Century Hutchinson Ltd., London pp 134-138.

Huang CH, Ku CY, Jan TR (2009). Diosgenin attenuates allergeninduced intestinal inflammation and $\mathrm{IgE}$ production in a murine model of food allergy. Planta Medica 75(12):1300-1305.

Izzo AA, Di Carlo G, Borrelli F, Ernst E (2005). Cardiovascular pharmacotherapy and herbal medicines: the risk of drug interaction. International Journal of Cardiology 98(1):1-14.

Jain V, Jain P, Sharma S, Kakani R (1995). Hypolipidaemic activity of syndrex, a hydroalcoholic extract of fenugreek seeds: Single blind 
clinical study. International Medicinal Journal 89:1-41.

Jani R, Udipi SA, Ghugre PS (2009). Mineral content of complementary foods. The Indian Journal of Pediatrics 76(1):3744.

Kamal R, Yadav R, Sharma GL (1987). Diosgenin content in fenugreek collected from different geographical regions of south India. Short communication. Indian Journal of Agricultural Sciences.

Khosla P, Gupta DD, Nagpal RK (1995). Effect of Trigonella foenumgraecum (Fenugreek) on serum lipids in normal and diabetic rats. Indian Journal of Pharmacology 27(2):89.

Kumar P, Kale RK, McLean P, Baquer NZ (2012). Antidiabetic and neuroprotective effects of Trigonella foenum-graecum seed powder in diabetic rat brain. Prague Medical Report 113(1):33-43.

Lee EL (2009). Genotype X environment impact on selected bioactive compound content of fenugreek (Trigonella foenum-graecum L.). Doctoral dissertation, Lethbridge, Alta.: University of Lethbridge, Department of Biological Sciences.

Lee J, Jung K, Kim YS, Park D (2007). Diosgenin inhibits melanogenesis through the activation of phosphatidylinositol-3kinase pathway (PI3K) signaling. Life Sciences 81(3):249-254.

Lepage C, Leger DY, Bertrand Y, Martin F, Beneytout JL, Liagre B (2011). Diosgenin induces deathreceptor-5 through activation of p38 pathway and promotes TRAIL-induced apoptosis in colon cancer cells. Cancer Letters 301(2): 193-202.

Li J, Liu X, Guo M, Liu Y, Liu S, Yao S (2005). Electrochemical study of breast cancer cells MCF-7 and its application in evaluating the effect of diosgenin. Analytical Sciences 21(5):561-564.

Li P, Mou Y, Lu S, Sun W, Lou J, Yin C, Zhou L (2012). Quantitative determination of diosgenin in Dioscorea zingiberensis cell cultures by microplate-spectrophotometry and high-performance liquid chromatography. African Journal of Pharmacy and Pharmacology 6(15):1186-1193.

Liagre B, Leger DY, Vergne-Salle P, Beneytout JL (2007). MAP kinase subtypes and Akt regulate diosgenin-induced apoptosis of rheumatoid synovial cells in association with COX-2 expression and prostanoid production. International Journal of Molecular Medicine 19(1):113-122.

Linnaeus C (1753). Species Plantarum Silvius. Stockholm pp 12001201.

Liu P, Wu XY, Yue DY (1993). Comprehensive utilization of diosgenin resources. Resource Economics Comprehensive Utility 12:47-49.

Madar Z, Abel R, Samish S, Arad J (1988). Glucose-lowering effect of fenugreek in non-insulin dependent diabetics. European Journal of Clinical Nutrition 42(1):51-54.

Madar Z, Shomer I (1990). Polysaccharide composition of a gel fraction derived from fenugreek and its effect on starch digestion and bile acid absorption in rats. Journal of Agricultural and Food Chemistry 38(7):1535-1539.

Manivannan J, Shanthakumar J, Silambarasan T, Balamurugan E, Raja B (2015). Diosgenin, a steroidal saponin, prevents hypertension, cardiac remodeling and oxidative stress in adenine induced chronicrenal failure rats. RSC Advances 5(25):19337-19344.
Martin E, Akan H, Ekici M, Aytac Z (2011). New chromosome numbers in the genus Trigonella L. (Fabaceae) from Turkey. African Journal of Biotechnology 10:116-125.

Mathern JR, Raatz SK, Thomas W Slavin JL (2009). Effect of fenugreek fiber on satiety, blood glucose and insulin response and energy intake in obese subjects. Phytotherapy Research 23(11):1543-1548.

McAnuff MA, Harding WW, Omoruyi FO, Jacobs H, Morrison EY Asemota HN (2005). Hypoglycemic effects of steroidal sapogenins isolated from Jamaican bitter yam, Dioscorea polygonoides. Food and Chemical Toxicology 43(11):1667-1672.

McAnuff MA, Omoruyi FO, Asemota HN (2006). Intestinal disaccharidases and some renal enzymes in streptozotocin-induced diabetic rats fed sapogenin extract from bitter yam (Dioscorea polygonoides). Life Sciences 78(22):2595-2600.

Meghwal M, Goswami TK (2012). A review on the functional properties, nutritional content, medicinal utilization and potential application of fenugreek. Journal of Food Processing and Technology 3(9):181.

Mitra A, Bhattacharya D (2006). Dose-dependent effects of Fenugreek composite in diabetes with dislipidaemia. International Journal of Food Safety 8:49-55.

Moradi N, Moradi K (2013). Physiological and pharmaceutical effects of fenugreek (Trigonella foenum-graecum L.) as a multipurpose and valuable medicinal plant. Global Journal of Medicinal Plant Research 1(2):199-206.

Naidu MM, Shyamala BN, Naik JP, Sulochanamma G, Srinivas P (2011). Chemical composition and antioxidant activity of the husk and endosperm of fenugreek seeds. LWT-Food Science and Technology 44(2):451-456.

Oliver-Bever BEP (1986). Medicinal plants in tropical West Africa. Cambridge University Press.

Pandian RS, Anuradha CV, Viswanathan P (2002). Gastroprotective effect of fenugreek seeds (Trigonella foenum-graecum) on experimental gastric ulcer in rats. Journal of Ethnopharmacology 81(3):393-397.

Pareek SK, Gupta R (1981). Effect of fertilizer application on seed yield and diosgenin content in fenugreek. 51(10):746-749.

Paroda RS, Karwasra RR (1975). Prediction through genotypeenvironment interactions in fenugreek (Trigonella foenum-graecum L.). Forage Research 1(1):31-39.

Petit PR, Sauvaire YD, Hillaire-Buys DM, Leconte OM, Baissac YG, Ponsin GR, Ribes GR (1995). Steroid saponins from fenugreek seeds: extraction, purification, and pharmacological investigation on feeding behavior and plasma cholesterol. Steroids 60(10):674-680.

Petropoulos GA (1973). Agronomic, genetic and chemical studies of Trigonella foenum-graecum $\mathrm{L}$. $\mathrm{PhD}$ Thesis, Bath University, England.

Petropoulos GA (2002). Fenugreek : the genus Trigonella. Taylor and Francis, London.

Petropoulos GA (2003). Fenugreek: the genus Trigonella. CRC Press, Science.

Petropoulos GA (2006). Fenugreek, the genus Trigonella. Taylor and 
30

Francis, London and Srinivasan K, Fenugreek (Trigonella foenumgraecum): A review of health beneficial physiological effects. Food Reviews International 22:203-224.

Prasad CKPS, Hiremath PC (1995). Varietal screening and chemical control foot-rot and damping-off caused by Rhizoctonia solani. Pesticides 19:34-36.

Qin TC, Zhang YD, Zhang JZ (1997). Distribution and utilization of diosgenin resources in Hubei province. Biological Resources 13:200-202.

Raghuram TC, Sharma RD, Sivakumar B, Sahay BK (1994). Effect of fenugreek seeds on intravenous glucose disposition in non-insulin dependent diabetic patients. Phytotherapy Research 8(2):83-86.

Raju J, Bird RP (2007). Diosgenin, a naturally occurring furostanol saponin suppresses 3-hydroxy-3-methylglutaryl CoA reductase expression and induces apoptosis in HCT-116 human colon carcinoma cells. Cancer Letters 255(2):194-204.

Raju J, Patlolla JM, Swamy MV, Rao CV (2004). Diosgenin, a steroid saponin of Trigonella foenum-graecum (Fenugreek), inhibits azoxymethane-induced aberrant crypt foci formation in F344 rats and induces apoptosis in HT-29 human colon cancer cells. Cancer Epidemiology, Biomarkers \& Prevention 13(8):1392-1398.

Rathore PS, Manohar SS (1989). Effect of date of sowing, levels of nitrogen and phosphorous on growth and yield of fenugreek. Madras Agricultural Journal 76(11):647-648.

Reger KH (1993). Hildegard Medizin. Die natürlichen Kräuterrezepte und Heilverfahren der hl. Hildegard von Bingen [The natural herbal recipes and healing procedures of St. Hildegard of Bingen]. W. Goldmann Verlag, München.

Ribes G, Sauvaire Y, Da Costa C, Baccou JC, Loubatieres-Mariani MM (1986). Antidiabetic effects of subtractions from fenugreek seeds in diabetic dogs. Experimental Biology and Medicine 182(2):159-166.

Roberts KT, Cui SW, Chang YH, Ng PKW, Graham T (2012). The influence of fenugreek gum and extrusion modified fenugreek gum on bread. Food Hydrocolloids 26(2):350-358.

Rosengarten F (1969). The book of spices. Livingston, Wynnewood, Pennsylvania, USA.

Rouk HF, Mangesha H (1963). Fenugreek (Trigonella foenum-graecum L.). Its relationship, geography and economic importance. Experiment Station Bulletin. No 20. Dire Dawa, Ethiopia. Imperial Ethiopian College of Agriculture and Mechanical Arts pp 120-127.

Sautour M, Mitaine-Offer AC, Miyamoto T, Dongmo A, LacailleDubois MA (2004). Antifungal steroid saponins from Dioscorea cayenensis. Planta Medica 70(1):90-92.

Sauvaire Y, Petit P, Broca C, Manteghetti M, Baissac Y, Fernandez AJ, Gross R, Roye M, Leconte A, Gomis R, Ribes G (1998). 4 Hydroxyisoleucine: a novel amino acid potentiator of insulin secretion. Diabetes 47(2):206-210.

Schauenberg P, Paris F (1990). Guide to medicinal plants. Lutterworth Press, Cambridge UK.

Sharma RD, Raghuram TC, Rao NS (1990). Effect of fenugreek seeds on blood glucose and serum lipids in type I diabetes. European Journal of Clinical Nutrition 44(4):301-306.

Sharma RD, Raghuram TC, Rao VD (1991). Hypolipidaemic effect of fenugreek seeds. A clinical study. Phytotherapy Research 5(3):145147.

Sharma RD, Sarkar A, Hazra DK, Misra B, Singh JB, Maheshwari BB (1996). Toxicological evaluation of fenugreek seeds: a long term feeding experiment in diabetic patients. Phytotherapy Research 10(6):519-520.

Shishodia S, Aggarwal BB (2006). Diosgenin inhibits osteoclastogenesis, invasion, and proliferation through the down regulation of $A k t, I \kappa B$ kinase activation and NF- $\mathrm{kB}-$ regulated gene expression. Oncogene 25(10):1463-1473.

Singh D, Singh A (1974). A green tilling mutant of Trigonella foenumgraecum L.(Methi). Crop Improvement 1(1-2):98-100.

Singh J, Gupta K, Arora SK (1994). Changes in the anti-nutritional factors of developing seeds and pod walls of fenugreek (Trigonella foenu-graecum L.). Plant Foods for Human Nutrition 46(1):77-84.

Singhal PC, Gupta RK, Joshi LD (1982). Hypocholesterolemic effect of Trigonella foenum-graecum L. Current Science 51(3):136-7.

Son IS, Kim JH, Sohn HY, Son KH, Kim JS, Kwon CS (2007). Antioxidative and hypolipidemic effects of diosgenin, a steroidal saponin of yam (Dioscorea spp.), on high-cholesterol fed rats. Bioscience, Biotechnology and Biochemistry 71(12):3063-3071.

Sowmya P, Rajyalakshmi P (1999). Hypocholesterolemic effect of germinated fenugreek seeds in human subjects. Plant Foods for Human Nutrition 53(4):359-365.

Srinivasan K (2006). Fenugreek (Trigonella foenum-graecum): A review of health beneficial physiological effects. Food Reviews International 22(2):203-224.

Srinivasan S, Koduru S, Kumar R, Venguswamy, G, Kyprianou N, Damodaran C (2009). Diosgenin targets Akt-mediated prosurvival signaling in human breast cancer cells. International Journal of Cancer 125(4):961-967.

Tada Y, Kanda N, Haratake A, Tobiishi M, Uchiwa H, Watanabe S (2009). Novel effects of diosgenin on skin aging. Steroids 74(6):504511.

Talelis D (1967). Cultivation of legumes. Agricultural College of Athens, Athens (in Greek) 101-105.

Trivedi PD, Pundarikakshudu K, Rathnam S, Shah KS (2007). A validated quantitative thin-layer chromatographic method for estimation of diosgenin in various plant samples, extract, and market formulation. Journal of AOAC International 90(2):358-363.

Uematsu Y, Hirata K, Saito K, Kudo I (2000). Spectrophotometric determination of saponin in Yucca extract used as food additive. Journal of AOAC International 83(6):1451-1454.

Uemura T, Goto T, Kang MS, Mizoguchi N, Hirai S, Lee JY, Nakano Y, Shono J, Hoshino S, Taketani K, Tsuge N (2011). Diosgenin, the main aglycon of fenugreek, inhibits LXR $\alpha$ activity in HepG2 cells and decreases plasma and hepatic triglycerides in obese diabetic mice. The Journal of Nutrition 141(1):17-23.

Vaidya K, Ghosh A, Kumar V, Chaudhary S, Srivastava N, Katudia K, Tiwari T, Chikara SK (2013). De Novo transcriptome sequencing in L. to identify genes involved in the biosynthesis of diosgenin. The Plant Genome 6(2):1-11.

Vaitsis T (1985). Creation of a new variety of fenugreek, named 'Ionia', 
resistant to Sclerotinia sclerotiorum (unpublished data).Fodder and Pastures Research Institute, Larissa, Greece.

Valette G, Sauvaire Y, Baccou JC, Ribes G (1984). Hypocholesterolemic effect of fenugreek seeds in dogs. Atherosclerosis 50(1):105-11.

Vidyashankar GK (2014). Fenugreek: An analysis from trade and commerce perspective. American Journal of Social Issues and Humanities.

Wang LJ, Wang Y, Chen SW, Ma JS, Fu Q, Wang BX (2002).The antitumor activity of Diosgenin in vivo and in vitro. China Journal of Chinese Materia Medica 27(10):777-779.

Wang YJ, Pan KL, Hsieh TC, Chang TY, Lin WH, Hsu JTA (2011). Diosgenin, a plant-derived sapogenin, exhibits antiviral activity in vitro against hepatitis $\mathrm{C}$ virus. Journal of Natural Products 74(4):580-584.

Xu L, Liu Y, Wang T, Qi Y, Han X, Xu Y, Peng J, Tang X (2009) Development and validation of a sensitive and rapid non-aqueous LC-ESI-MS/MS method for measurement of diosgenin in the plasma of normal and hyperlipidemic rats: A comparative study. Journal of Chromatography B 877(14):1530-1536.
Yan LL, Zhang YJ, Gao WY, Man SL, Wang Y (2009). In vitro and in vivo anticancer activity of steroid saponins of Paris polyphylla var. yunnanensis. Experimental Oncology31(1):27-32.

Yoshikawa M, Murakami T, Komatsu H, Murakami N, Yamahara J, Matsuda H (1997). Medicinal foodstuffs. IV. Fenugreek seed. (1): Structures of trigoneosides Ia, Ib, IIa, IIb, IIIa, and IIIb, new furostanol saponins from the seeds of Indian Trigonella foenumgraecum L. Chemical and Pharmaceutical Bulletin 45(1):81-87.

Young ND, Mudge J, Ellis TN (2003). Legume genomes: more than peas in a pod. Current Opinion in Plant Biology 6(2):199-204. 